\title{
Soluble fractalkine in the plasma of fibromyalgia patients
}

\author{
JUAN J. GARCIA and EDUARDO ORTEGA \\ Immunophysiology Research Group, Department of Physiology, \\ Faculty of Sciences, University of Extremadura, Badajoz, 06071, Spain \\ Manuscript received on February 28, 2013; accepted for publication on April 3, 2014
}

\begin{abstract}
Fibromyalgia is a form of non-articular rheumatism in which inflammatory cytokines seem to be involved. However, there is still no analytical specific diagnostic criterion for this disease. The aim was to examine a possible role of fractalkine as a biomarker in fibromyalgia. Plasma levels of soluble fractalkine were compared between women diagnosed with fibromyalgia $(n=17)$ and healthy women $(n=10)$ as controls. Fractalkine released by monocytes was also evaluated. Fibromyalgia patients showed lower plasma fractalkine than healthy women. Since most inflammatory pathologies show elevated plasma levels of soluble fractalkine, the results may contribute towards a differential diagnosis for fibromyalgia.
\end{abstract}

Key words: fractalkine, fibromyalgia, biomarker, chemokine, monocyte.

\section{INTRODUCTION}

Fibromyalgia (FM) is a form of non-articular rheumatism defined as the presence of a prolonged history ( $>3$ months) of chronic generalized musculoskeletal pain (Wolfe et al. 2010). There is still no specific analytical diagnostic criterion for this pathology. Among the posited ætiologies of FM, special attention has been paid to the hypothesis of the involvement of inflammatory cytokines (Van West and Maes 2001), especially IL-8 (CXCL8) (Ortega et al. 2009, Bote et al. 2012).

Fractalkine (CX3CL1) is a special inflammatory chemokine with chemotactic activity for monocytes, NK cells, and T cells. It also acts as an adhesion molecule for leukocytes (Jones et al. 2012), and is a mediator of pathological pain (Milligan et al. 2008). Evidence has been emerging regarding

Correspondence to: Juan José García

E-mail:jjgarcia@unex.es its active role in many rheumatic diseases. These include rheumatoid arthritis, Sjogren's syndrome, systemic lupus erythematosus, and scleroderma, as well as other diseases associated with systemic inflammation in which it is always found at high levels (Jones et al. 2012). For this reason, the aim of this study was to compare plasma levels of soluble fractalkine in women diagnosed with fibromyalgia when compared with control healthy women.

The subjects of the study were 17 volunteer patients (all women, aged 32-60 years) diagnosed with FM by a rheumatologist (according to the American College of Rheumatology criteria for the syndrome) (Wolfe et al. 2010). The exclusion criteria were: neoplastic disorder (as determined from the patient's medical history); infection; cardiopulmonary, vascular, or other internal medical conditions; and oral or local corticosteroid or anticytokine therapy that might affect cytokine 
levels. FM patients were classified as belonging to the primary group (with no definitive organic factor triggering the syndrome) according to the classification criteria of Müller et al. (2007) - i.e., Group I: FM with sensitivity to pain but no diagnosis of depression or other relevant psychiatric disorder. Ten sedentary healthy women (HW), who had no symptoms of pain or infectious illness at the time of blood sampling, served as age-matched controls (aged 25-55 years). The levels of soluble CX3CL1 in the plasma and in the supernatants of isolated ("Monocyte Isolation Kit II", MiltenyiBiotec $\mathrm{GmbH}$, BergischGladbach, Germany) cultured monocytes were determined using an enzymelike immunoassay (RayBio ${ }^{\circledR}$ Human Fractalkine ELISA Kit, RayBiotech, Norcross, USA). Statistical comparisons were done using the parametric Student's $t$-test. The results are presented as the mean ( \pm standard error of the mean).
The plasma concentration of CX3CL1 in FM patients was lower than in the HW group ( $<<0.001$; Fig. 1). However, the production of soluble fractalkine by isolated monocytes was not different between FM patients and HW ( $p>0.05$; Fig. 2).

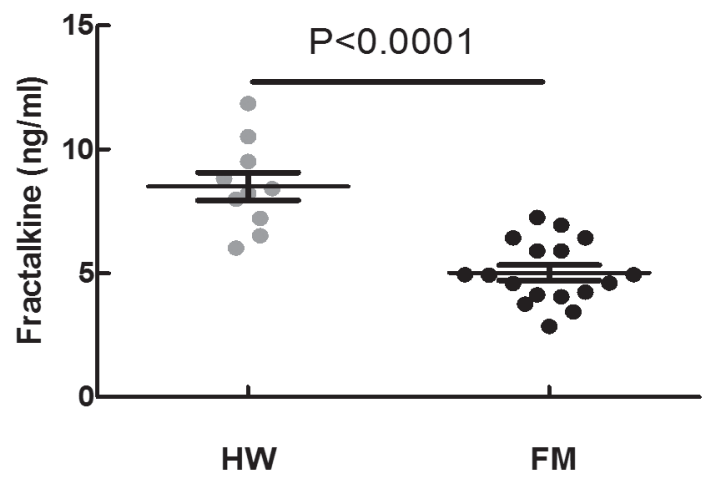

Figure 1 - Plasma levels of soluble fractalkine (CX3CL1) in fibromyalgia patients (FM) and in healthy women (HW). The soluble CX3CL1 level in the FM group was $5.021( \pm 0.308$ SEM) $\mathrm{ng} / \mathrm{ml}$ and in the HW group $8.511( \pm 0.563 \mathrm{SEM}) \mathrm{ng} / \mathrm{ml}$; $\mathrm{p}=0.0001$, Student's $t$-test).
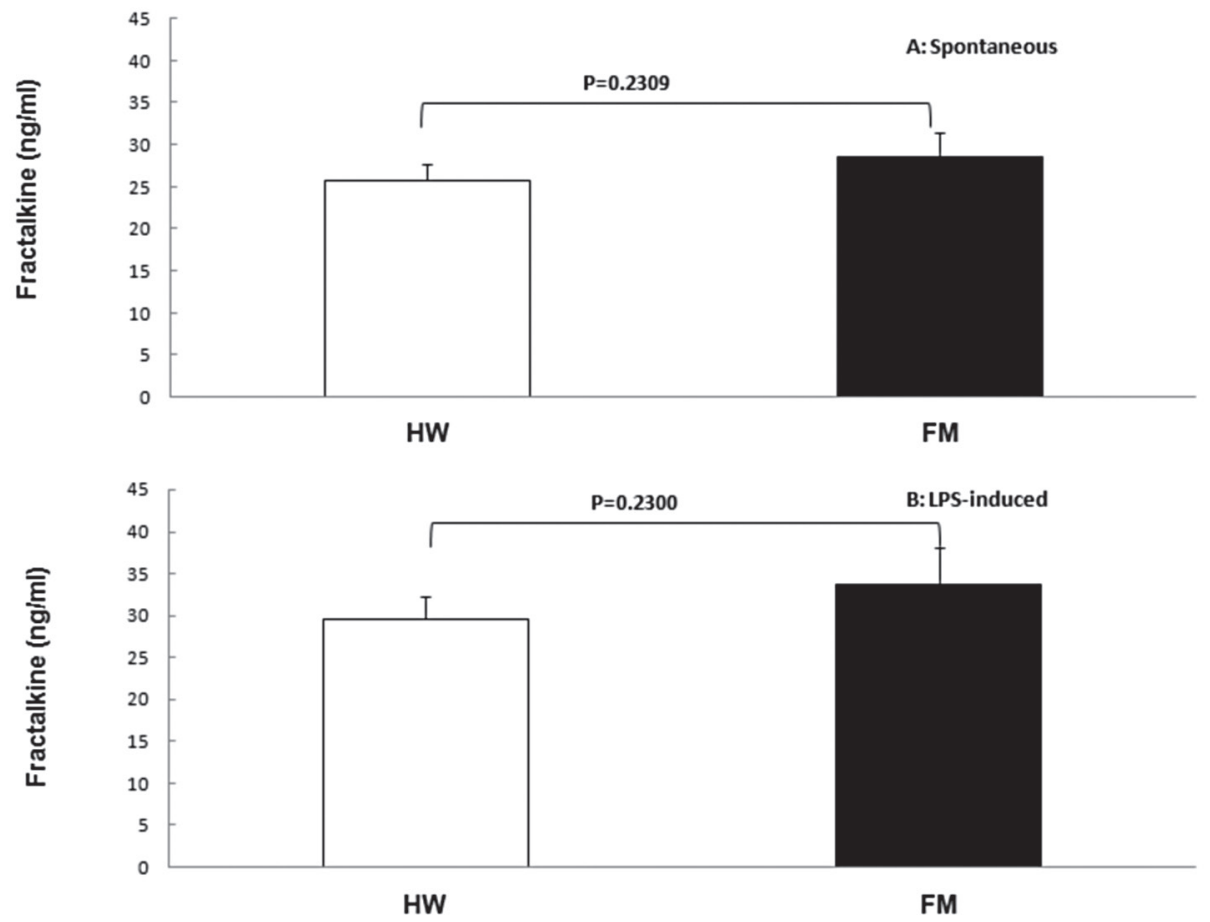

Figure 2 - Soluble fractalkine (CX3CL1) release by non-activated (A: spontaneous) and lipopolysaccharide-activated (B: LPS-induced) monocytes from healthy women (HW) and from fibromyalgia patients (FM). Each column represents the mean \pm SEM of ten experiments performed in duplicate (one experiment per volunteer). 
To the best of our knowledge, this is the first study in evaluating fractalkinein fibromyalgia. Soluble CX3CL1 is generated by the limited proteolysis of ADAM ("a disintegrin and metallopeptidase") metallopeptidase domain 10 (ADAM10) and ADAM17 (also called TACE - tumour necrosis factor- $\alpha$-converting enzyme) (Garton et al. 2001, Hundhausen et al. 2003). This appears to suggest that the lower concentration in the plasma of fibromyalgia patients may be due to a functional defect of ADAM10 and/or ADAM17. However, the capacity of isolated monocytes to produce soluble CX3CL1 was similar in the fibromyalgia patients and in the healthy women, so that, at least in monocytes, it does not seem that the functionality of ADAM10 and/or ADAM17 (which are present in monocytes) is affected in fibromyalgia. Although further studies are needed to clarify the mechanisms underlying the decrease of soluble CX3CL1 in the plasma from fibromyalgia patients; particularly differences in the affinity of fractalkine to its receptor CX3CR1 between FM patients and $\mathrm{HW}$, as well as to evaluate potential changes in the CX3CR1 expression in FM patients. This lower concentration should be another differentiating element between this syndrome and most other inflammatory rheumatic diseases, in which this chemokine is usually increased in plasma (Jones et al. 2012). Then, plasma level of soluble fractalkine could contribute as a biomarker for the differential diagnosis of fibromyalgia compared with other inflammatory conditions.

\section{ACKNOWLEDGMENTS}

This work was supported by FundeSalud (PRIS10019) and Junta de Extremadura-FEDER (GR10020).

\section{RESUMO}

A fibromialgia é uma forma de reumatismo não articular, em que as citocinas inflamatórias parecem estar envolvidas. No entanto, ainda não há um critério de diagnóstico específico de análise para esta doença. O objetivo foi examinar um possível papel de fractalcina como um biomarcador para a fibromialgia. Os níveis plasmáticos de fractalcina solúvel foram comparados entre as mulheres diagnosticadas com fibromialgia $(n=17)$ e mulheres saudáveis $(\mathrm{n}=10)$ como controle. Fractalcina liberada por monócitos também foi avaliada. Pacientes com fibromialgia mostraram níveis plasmáticos de fractalcina mais baixos do que mulheres saudáveis. Como a maioria das patologias inflamatórias apresentam níveis plasmáticos elevados de fractalcina solúvel, os resultados podem contribuir para um diagnóstico diferencial para a fibromialgia.

Palavras-chave: fractalcina, fibromialgia, biomarcador, quimiocina, monócito.

\section{REFERENCES}

Bote ME, Garcia JJ, Hinchado MD AND ORTEga E. 2012. Inflammatory/stress feedback dysregulation in women with fibromyalgia. Neuroimmunomodulation 19: 343-351.

Garton K, Gough P, Blobel C, Murphy G, Greaves DR, DEMPSEY PJ AND RAINES EW. 2001. Tumor necrosis factor-alpha-converting enzyme(ADAM17) mediates the cleavage and shedding of fractalkine (CX3CL1). J Biol Chem 276: 37993-38001.

HUNDHAUSEN C ET AL. 2003. The disintegrin-like metalloproteinase ADAM10 is involved in constitutivecleavage of CX3CL1 (fractalkine) and regulates CX3CL1-mediated cell-celladhesion. Blood 102: 1186-1195.

Jones B, Kock A AND AHMEd S. 2012. Pathological role of fractalkine/CX3CL1 in rheumatic diseases: a unique chemokine with multiple functions. Front Immunol 2: 82.

Milligan E, Sloane E AND Watkins L. 2008. Glia in pathological pain: A role for fractalkine. J Neuroimmunol 198: 113-120.

MÜller W, Schneider EM And Stratz T. 2007. The classification of fibromyalgia syndrome. Rheumatol Int 27: 1005-1010.

Ortega E, Garcia JJ, Bote ME, Martín-Cordero L, ESCALANTE Y, SAAVEDRA JM, NORTHOFF H AND GIRALDO E. 2009. Exercise in fibromyalgia and related inflammatory disorders: known effects and unknown chances. Exerc Immunol Rev 15: 42-65.

VAN WEST D AND MAES M. 2001. Neuroendocrineand immune aspects of fibromyalgia. Bio Drugs 15: 521-531.

Wolfe F, Clauw DJ, Fitzcharles MA, Goldenberg DL, Katz RS, Mease P, Russell AS, Russell IJ, Winfield JB AND Yunus MB. 2010. The American College of Rheumatology preliminary diagnostic criteria for fibromyalgia and measurement of symptom severity. Arthritis Care Res 62: 600-610. 
